\title{
SANDRA PANNELL \\ Of gods and monsters \\ Indigenous sea cosmologies, promiscuous geographies and the depths of local sovereignty
}

\section{Introduction}

In a recent volume on 'Customary marine tenure in Australia', the editors point to an 'ethnographic blind spot' regarding the documentation of indigenous people's relationship with the sea (Peterson and Rigsby 1998:2). In offering various explanations for this state of affairs, Peterson and Rigsby raise the idea that not all coastal-dwelling people have systems of customary marine tenure or necessarily rely upon the sea for their livelihood. ${ }^{1}$ This idea was initially proposed by Nicolas Polunin (1984:272), who suggested that one of the reasons for this is that 'people in several areas tend [...] to be averse to the sea'. In his consideration of the evidence from Indonesia and Papua New Guinea, Polunin (1984:272) describes how the Balinese view the sea as polluted by the 'filth of the land', in contrast to the purity of the mountains, regarded as the 'seat of the gods'. The Javanese, on the other hand, view the sea as a 'wilderness beyond the control of human society' (Polunin 1984:271), a 'supernatural background drea ... of the sea' apparently also shared by the Tanga Islanders of Papua New Guinea (Polunin 1984:272).

While Polunin hints at the association of the sea with evil spirits and monsters, other writers link the sea to various deities and ancestors. For example, in the Kei Islands of eastern Indonesia, Cécile Barraud discusses the ancestors of the village society of Tanebar-Evav. These ancestors are collectively known as wadar, and are said to be eighteen men and women who went to sea and subsequently disappeared. These ancestral figures, also referred to as 'our fathersgrandfathers', are ritually offered people's catch from the sea, including 'parts of dolphins, sea-cows [dugongs] and turtles' (Barraud 1990:43). In other Indo-

1 Due to local hostilities and open warfare, many societies throughout Indonesia, for example, traditionally built their villages on hilltops some distance from the coast. In the course of Dutch 'pacification' of the population, many of these village societies were forced to move down to the coast and occupy village sites which could be more effectively accessed and controlled by the Dutch (see De Jonge and Van Dijk 1995). 
nesian societies, such as the seafaring Bajo people of southeast Sulawesi, ${ }^{2}$ the ancestors not only inhabit the sea but they also accompany people on their long maritime voyages around the archipelago. Writing of the Bajo of the Tukang Besi Islands, Natasha Stacey (1999:71) observes that Mbo Madilao, the 'ancestors of the sea', are not 'confined to any particular location but live "wherever there is sea"'. Stacey (1999:71) concludes that 'the spiritual maritime domain of the Bajo has no boundaries, it is infinite'. As such, it encompasses politicallycharged areas within the Exclusive Economic Zone (EEZ) claimed by Australia under the 1982 United Nations Law of the Sea Convention.

In Australia, indigenous sea cosmologies also have far-reaching political and legal ramifications. For example, in the seas surrounding Croker Island in northern Australia, the Dreamtime figure of the Rainbow Serpent lies beneath the water, resting on the seabed. ${ }^{3}$ Around this island, Aboriginal people refrain from throwing meat overboard in fear that it will 'arouse the local Rainbow Serpent' (Peterson and Rigsby 1998:6) which, when disturbed, may manifest itself as a cyclone, a waterspout or tidal floods (see Memmott and Trigger 1998:121). These beliefs about the Rainbow Serpent and the danger it poses have recently been put to the test in the Croker Island native title case, ${ }^{4}$ where the question of Aboriginal ownership of the seabed and their exclusive possession of offshore waters is at issue.

As these ethnographic examples from Indonesia and Australia suggest, indigenous cosmologies implicate specific geographic features or environments, in the process defining a landscape of memory, action and identity. James Fox (1997:8) notes that cosmologies often take the form of 'topogeny' - 'the recitation of an ordered sequence of place names'. Fox observes that 'topogenies' may recount the journey of an ancestor or the migration of a group. For instance, cosmological narratives in eastern Indonesia often refer to the sea voyages of ancestral figures as they migrate from their point of origin, usually an island, to the place of their eventual settlement. In many eastern Indonesian societies, these narratives underpin local orders of precedence and the division of authority into ritual and secular domains. Fox also notes that topogenies may refer to the movement of objects. To illustrate this latter point, he briefly alludes to a Rotinese narrative which describes the journey of 'two great rocks that eventually came to settle along the north coast of the island' (Fox 1997:9).

In northern Australia, indigenous sea cosmologies, often in the form of detailed song cycles, refer to the creation of islands and the journeys of ancestral Dreaming-beings across large bodies of open sea. For example, in

2 Also known as 'sea nomads', 'sea gypsies', 'Bajau Laut' and orang laut ('sea people') (Stacey 1999:1).

3 The Rainbow Serpent, a mythological figure similar to the giant water snake or Naga recognized in many parts of Southeast Asia, is a pervasive image throughout indigenous Australia (see Maddock and Buchler 1978; Radcliffe-Brown 1926).

4 Formally known as Yarmirr v Northern territory (1998) 156 ALR 370. 
the Wellesley Islands, in the southern Gulf of Carpentaria, the site known as Ngaliwan, consisting of three rocks rising from the sea, is regarded by Lardil people as the bodies of their ancestors, while the Shark Dreaming is said by Lardil people to travel along the northwest coast of Mornington Island planting cycad seeds at the places where it stopped (Memmott and Trigger 1998:119-120). In the Wellesley Islands, these Dreamings are linked to individual totemic identity, as well as being accorded an important ritual status in regional initiation ceremonies.

As a number of studies from north Australia indicate, the journeys and the sites associated with these Dreaming-beings often serve as the basis for claims of estate group ownership or for the assertion of individual rights and interests (see Peterson and Rigsby 1998). In eastern Indonesia a similar situation exists. Discussing cultural topographies in West Timor, Andrew McWilliam (1997:111) observes that in Meto society origin narratives not only link a named group with significant places but they also serve as a 'legitimizing discourse and statement of claim to land'. This is a point also made by Pannell (1997a) in her examination of the social and political ramifications of invoking traditional 'topostories' in coastal boundary and marine resource disputes on the island of Damer.

As these comments suggest, in Indonesia and Australia indigenous cosmologies are implicated in local perceptions of territoriality and resource ownership. In this respect, they often function, to borrow Michel de Certeau's term (1984:122), as forms of 'spatial legislation'. The efficacy of cosmologies to serve as spatial legislation or as the foundation of sovereign power is not simply a function of an association between founding figures and certain places. These cosmologies also constitute moral discourses, inculcating cultural values regarded as intrinsic to the customary order of things and people. As indigenous parables, these narratives profess a certain truth or 'ultimate verity' (Herzfeld 1987:13) about the world. On the basis of this claim to identify the fundamental conditions (and limits) of truth, indigenous sea cosmologies can be regarded as potent political statements about the nature of knowledge and power, on both a minute and monumental scale.

In plotting assertions of territorial sovereignty or indigenous orders of moral authority, these cosmologies translate into a cultural landscape where certain places are valued as keramat ('sacred'), pemali ('taboo'), suci ('holy'), jahat ('evil'), panas ('hot') or bahaya ('dangerous'), linked as they are to a pantheon of gods and monsters. ${ }^{5}$ Liisa Malkki (1995:55-6) refers to this imagina-

5 Throughout this article, Indonesian terms are presented in italics and identified with the abbreviation 'BI'. Unless otherwise stated, all other italicized words are terms from the Austronesian language spoken on Luang. As a result of the limited nature of linguistic research on the language spoken on Luang (see Grimes 1996; Taber 1996), the orthography used in this article for local language terms is largely based upon the phonetic system used by informants. 
tive labour of mapping affect and experience as 'worldmaking' and suggests that making the world through narrative is sometimes an oppositional process concerned with remaking 'the moral order of the world' and recasting identity and history.

This article explores the often contested and sometimes subversive relationship posited between cosmological narratives, space and sovereign power through a consideration of ethnographic examples from eastern Indonesia and Aboriginal Australia. In focusing upon the articulation of indigenous 'sea cosmologies' as spatial discourses, I attempt to go beyond the popular view of these accounts as quaint or fabulous stories referring to a creative epoch in a dim and mystical past. Instead, the emphasis of this article is upon the role of this spatial imaginary in the assertion of local sovereignty and in the creation of what Jane Jacobs (1996:5) calls 'promiscuous geographies of dwelling in place'. As the histories of Indonesia and Australia graphically demonstrate, the exercise of power and the politics of cultural identity are primarily about space. In his spatial history of colonial discovery and settlement in Australia, Paul Carter (1987) reminds us that space is not simply a backdrop or stage upon which significant events take place or are inscribed upon. To paraphrase Carter (1987:xxii), a culture declares its presence through 'spatial forms and fantasies'. These spatial forms and fantasies are part of 'an ever-shifting social geometry of power and signification' (Massey 1994:3). In this regard, the cosmological landscapes considered in this article represent 'geographies which struggle' (Said 1993:7), vividly disturbing the notion of space, identity and authority as somehow inherently fixed or settled. ${ }^{6}$

\section{Landscapes with sea views: space and discourse}

In a number of European languages, the term 'landscape' originally referred to a province, a district or an area of land, in other words, a geographical region. Thus, in Europe in the early 1500s regional maps were described as 'landscapes' (landschap in Dutch) and their production constituted an exercise in chorography. The notion of chorography, with its emphasis upon regions, can be contrasted with the Ptolemic concept of geography, which entails the representation of the entirety of the known world. ${ }^{7}$

The concept of landscape which we are familiar with today is of landscape as pictorial subject matter rather than as a geographical region. However, the

6 Throughout this article, I use the term 'landscape' in its broadest connotation to refer to spatial histories with both a marine and terrestrial focus.

7 As previously noted, the Dutch concept of landschap originally referred to a small area of land, which was viewed as an inset of a much larger region or context. The concept of chorography emerged as a way of representing and talking about this form of confined perspective. In this respect, landschap coincides with the German meaning of the word Landschaft (see Bender 1993:2). 
regional connotation of the word landscape still persists in terms of the scope or prospect of the artistic subject matter. Although the concept of landscape has been unhooked for some time from its original art associations (see Bender 1993; Hirsch and O'Hanlon 1995), there is still a dominant view of landscape as an inscribed surface, akin to a map or a text, from which cultural meaning and social forms can simply be read.

Susan Kuchler refers to the view of landscape as inscribed or associated surface as the 'landscape of memory', wherein memories (or meanings) are somehow captured in, or represented by, the form of visual landmarks. She points out that in this view the idea of landscape is not 'affected by the project of its representation and remembrance' (Kuchler 1995:104). Kuchler (1995:85) contrasts this view of landscape as the encoding of memory and meaning with the notion of 'landscape as memory'. In this perspective, landscape is implicated in both the dynamic and interactive social processes of memory-making as well as being one of the products of these on-going processes.

The historian, Paul Carter, is another scholar who takes issue with the idea of space as a backdrop or stage upon which significant events, such as European discovery or an indigenous 'Dreamtime', take place or are inscribed. Similarly, Carter is critical of the view which presents physical surroundings as merely this. As Carter (1987:349) points out in his book, The road to botany bay, what is symbolized is not 'the physical country' per se but 'the enactment of [an already] historical space'. In other words, references to such things as physical country can only be made by means of the cultural representations of those things.

Carter draws our attention to the importance of realizing that a cultural landscape, whether indigenous or European, signifies more than just another way of representing or symbolizing geographical entities or natural surroundings. Representation constitutes just one facet of people's interaction with and experience of their environment. As this statement suggests, landscape can be seen not only as a complex cultural product but as a dynamic one as well.

Drawing upon the work of Kuchler, Carter, Bender and others, this article adopts a view of landscape as both an immanent and emergent cultural construct which is informed by and, in turn shapes, historical experiences and social relations. Put another way, landscapes can be regarded as both the objects and effects of specific discourses. If landscapes are created by humans, then they are also contested, disputed and, at times, denied by them. In this sense, the idea of landscape can be regarded as a 'concept of high tension' (Inglis 1977), often enacted at the interstices of history, politics, and society. One is reminded here of Simon Schama's warning (1995:18) that not all landscapes are 'places of delight', nor are all memories 'pastoral picnics'. Schama's cautionary words (1995:18) refer to the horror and tragedy often encountered on the 'trail of social memory'. 


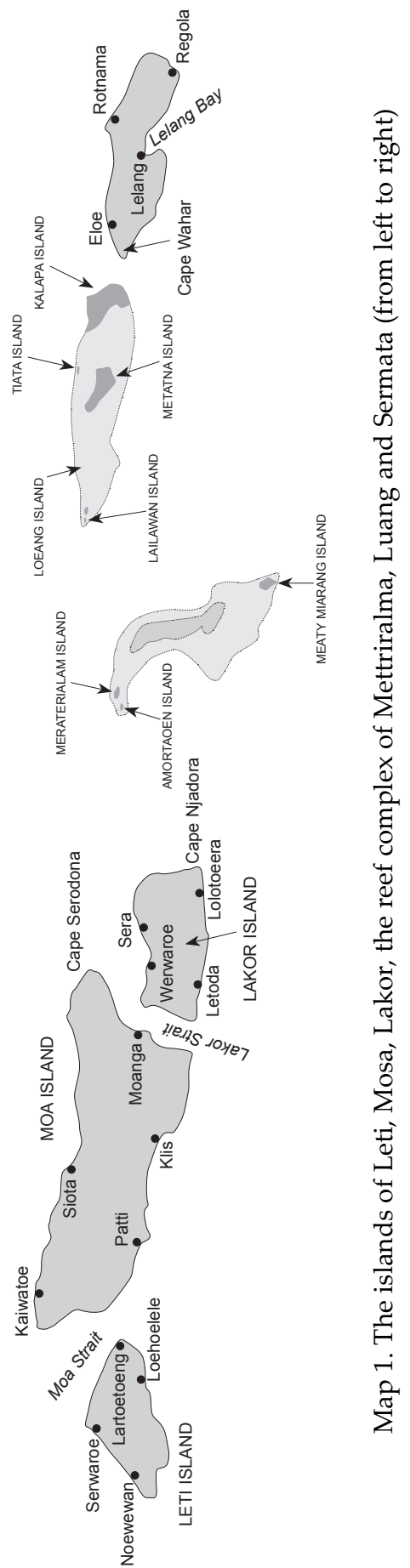




\section{Gods and monsters I: discursive landscapes in Luang}

The island of Luang (known in the local Austronesian language as Lgona) is about as far away as you can get from Jakarta and still be in Indonesia. It is located in the southernmost waters of the Banda Sea, and is marginally closer to Darwin than it is to the provincial capital of Ambon. Covering an area of only eight square kilometres, Pulau Luang (BI) is well known in the region for its near absence of trees, scarcity of drinking water ${ }^{8}$ and its extensive reefs which, covering some 350 square kilometres, makes it the second largest reef system in Indonesia. This reef complex consists of the home reef system, centred upon the island of Luang, and the barrier reef system of Mettriralma ('within the reef'), situated some twenty five kilometres southwest of Luang (see Map 1). The sea surrounding the two reef complexes drops off quickly from the edge of the reef to a depth of some 2000 metres (hleta, 'deep sea'), making the passage between the two reef systems quite rough and, at times, quite dangerous. The 1800 or so inhabitants of Luang reside in two villages - Luang Timur and Luang Barat (BI). The residents of Luang are also well known in the region, largely because they constitute a highly mobile sailing population and because of the widespread belief that they live entirely on fish and other marine resources. While rarely found on maps these days, Luang occupies a pivotal place in the cosmological landscape of the region.

Throughout Maluku Tenggara, the island of Luang is widely acknowledged as the respective geomorphological and ontological source of the islands and societies in this part of Maluku. I recorded one account of how this came to be from a ritual specialist from the island of Damer:

In the past, so the narrative goes, Pulau Luang was a sizeable, mountainous island with a large population of people. A sailfish, named Upo Hrui cut through the island with its dorsal sailfin, shattering it into many pieces. These terrestrial fragments of Luang became the islands which now comprise Maluku Tenggara. The island of Luang itself was reduced to a small speck in the Banda Sea. The people of Luang were unable to live on this island fragment and so many left to settle the other islands created by Upo Hrui.

My informant then proceeded to narrate the history of settlement on the island of Damer resulting from the actions of the sailfish (BI ikan layar) Upo Hrui: ${ }^{9}$

The Tuan Tanah of Luang, from the house of Wolonteri, sailed by perahu [BI] to what is now the island of Damer. The perahu ran aground on the exposed summit of Gunung Lumtuni when the rudder became entangled in the moss/algae

8 According to local government statistics, Luang receives an average annual rainfall of 150 $\mathrm{mm}$.

9 On Damer, upo is the generic term for ancestor whereas on Luang, the term upa is used. 
(lumtun) which covered the mountain. As the sea receded, the Wolonteri ancestors descended down the mountain in the perahu, stopping at various places and performing certain activities. These exploits are captured in the names ascribed to these places. The Wolonteri ancestors changed their name to Surlialy and, as the first group to arrive on the island, proclaimed themselves lelehro [Western Damer Language] or rajah (BI 'king').

Other island societies in Maluku Tenggara have similar origin stories linked to the Upa Hrui narrative which depict the establishment of pre-colonial polities in the region.

While the account from Damer identifies the reason for the dispersal of the original population as overcrowding, other versions of the Upa Hrui narrative I recorded on Luang specifically identify incessant warfare between the eleven autonomous polities on the island as the explanation for the wholesale departure of six of the original indigenous states. The inhabitants of these six polities eventually settled on the islands of Seram, Tanimbar, Kei, Sermata, Timor, Kisar, Lakor, Teun and Damer. As this suggests, the Upa Hrui narrative is as much a 'colonization myth' (Geertz 1960:23) as it is an account of creation.

As a creation story, however, the Upa Hrui narrative has an ambiguous status. For it is as much a story about the transformation and differentiation of the world as it is an account of its origin and nature. In this respect, the narrative emphasizes destruction and dispersal, disruption and displacement as essential elements in the cosmological process. An indigenous equivalent to the second Law of Thermodynamics if you like. The Upa Hrui narrative can be regarded as an inter-linked set of cosmological and moral ordering stories which converge to make and, perhaps more importantly, remake the world.

While conducting research on the island of Luang, I recorded detailed versions of the sailfish narrative from a number of senior men. Akin to a Shakespearean drama, these versions use an affinal arrangement between Luang and the ancestral village of Melai Watukali in East Timor to explore what is a common theme in Indonesian cosmologies, the rivalry between elder and younger brothers. At the heart of these accounts is the betrayal of the younger brother's wife (who originates from Melai Watukali) and her marriage to the wealthier older sibling (from Luang) called Rettiau Lay. In retaliation for this breach, the younger brother, Rettiau Ruru, with the assistance of Rarilmietma Rarlelkialwa, an old woman referred to as putri laut (BI 'queen of the sea'), calls up the sailfish, Upa Hrui, from the depths of the ocean. The younger brother climbs on the back of the sailfish and orders it to destroy the island of Luang so that 'people will not be able to say it's name anymore' - a reference to the affective power and political potency of place names on Luang. According to this account: 
The sailfish jumped out of the water and cut across Luang creating Mettutun. It jumped out of the water again and cut up the islets of Donna, Liakra, Kapuri and Tiata. The whole of Luang shook as the sailfish jumped across the island. People became afraid and fled Luang to the other islands in the region. Eventually the sailfish and the younger brother were stopped by an old woman, Surriai, who pleaded with the sailfish and her grandson [the younger brother] not to entirely destroy the island of Luang, not to shatter the earth. In her efforts to halt these destructive forces, she became a large boulder at Tutungain [BI muka tanjung or 'front of the cape'] while the sailfish became the island of Upa Hrui. ${ }^{10}$

From the Upa Hrui narrative it would appear that transgressions of the social and moral order evoke equivalent cataclysmic repercussions, in this case, the dispersal of society and destruction of the known world. ${ }^{11}$ In this sense, the narrative can be thematically likened to biblical stories, European fairytales, and Aboriginal Dreaming accounts (see Stanner 1989). Like Aboriginal cosmologies, people on Luang are spatially confronted with the displacing and dangerous effects of transgression and indiscretion in their physical engagement with the landscape created by Upa Hrui.

The Upa Hrui narrative not only recounts the fundamental formation of the islands of this region but it also provides explanations for their specific geomorphological features. For example:

The sailfish and the younger brother surfaced from the depths of the sea between Timor and Kisar. When they surfaced, the sailfish was facing south. He wanted to test his strength against the island of Timor and in doing so he cut off the tip of the island called Nohmehi. Then he turned around and headed straight for Kisar and the island shook vigorously. Because of this the mountains of Kisar are at the edge of the island and the villages are in the middle of the island. Then Upa Hrui headed north to Romang and destroyed the western side of the island, in the process creating Pulau Nohyata Roma.

Susan McKinnon records that in Tanimbarese cosmological narratives the geomorphological differentiation of the world is a task undertaken by prospective bridegrooms from offshore islands, in lieu of a hefty bridewealth payment. As McKinnon (1991:45) points out, these Herculean tasks made marriage with distant others 'virtually impossible', thus maintaining the 'selfcontained unity of the [Tanimbarese] world'.

10 In some accounts of this master narrative, Upa Hrui cuts through the island of Luang with its bill, in other versions, it is the dorsal sail fin that slices up the island. In a number versions I have recorded, Upa Hrui trails a long rope from its mouth, which it acquired from the old woman of the sea, and it is this rope that cleaves Luang into the islands which comprise Maluku Tenggara today.

11 Cécile Barraud (1985:122) makes a similar point with regard to the implications of 'incest, adultery and murder' in Tanebar-Evav society. According to Barraud (1985:122), 'the whole society [...] is destroyed in [the] case of such misconduct'. 


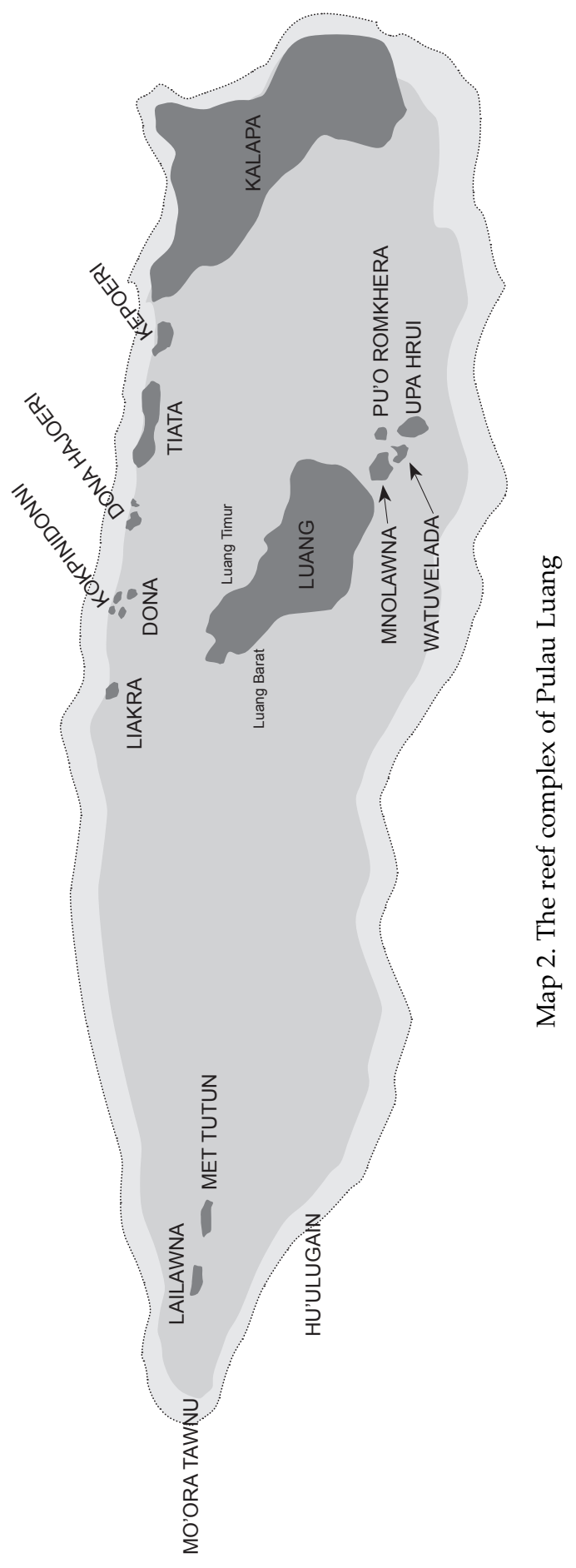


On Luang, this relationship between local and distant bride-givers and bride-receivers, expressed in terms of the alliance between Luang and Melai Watukali, is the subject of a number of related narratives which are set in, and give further definition to, the cosmological landscape recreated by Upa Hrui.

In common with Aboriginal totemic accounts, the landscape of Luang comprises a rich geography of named places and powerful beings (see Map 2 and Map 3). As one informant observed, semua tempat yang ada nama, punya orang dan sejarah (BI 'all places which have a name, have a person and a history associated with them'). An observation similar to Claude Lévi-Strauss's comment (1966:168) that 'space is a society of named places'.

These named places include various types of beaches, capes and points, islands, submerged and exposed rocks, spits, sandbars, submerged reefs, areas of deep water, tidal areas, and areas where strong currents and whirlpools are encountered. The names bestowed often evoke what is regarded as the primary physical feature of a place. For example, hnyariwarta or 'west door', refers to one of only two passages through the barrier reef at Mettriralma. A name may also evoke a resemblance, as in the case of Donna Hayuri or 'buffalo horn rock', or be historically invigorated by an event. For instance, Watuvlada, the white rock said to be a petrified Dutchman whose boat apparently ran aground on the reef in the VOC period. Throughout the reef complex, there are a number of stone boats $\left(p u^{\prime} o\right)$. For example, the rocky islet in the vicinity of Pulau Upa Hrui is identified as a perahu (BI 'traditional sailing vessel') from the island of Romang (pu'o romkhéra), replete with the fossilized belongings of its occupants, while at Mo'ora Liwutenna (BI 'pusat meti' or 'navel of the reef'), the western point in the Mettriralma reef complex, one can see the stone keel of a perahu from Melai Watukali. In addition to these stone perahu, it is also possible to see the wrecks of a number of wooden perahu which have run aground in the reef systems of Luang and Mettriralma.

The names of other places in the reef system may appear quite general or neutral in terms of their lexical meaning yet are associated with quite significant cosmological events and figures. The uninhabited island of Mnolawna illustrates this point. Translated as 'big place', at one level, the name of the island refers to its size in relation to the surrounding islands. At another level, however, the name captures the former status of the island as the peak of the highest mountain on Luang, located in the middle of the island (nohophoraraiарnu). On the summit of this mountain are situated the 'stairs' and the 'rope' (retna lotna), which not only connect the sky with the earth but also allow humans to access and communicate with the 'ancestral sun' being known as Upléra Mermetma, Upléra Warwarha. ${ }^{12}$ This being is described by people on

12 Up or upa is the local term generally used for ancestral figures, while the term lera specifically refers to the sun. As Marshall Sahlins (1985:18-9) points out with respect to Hawaiian chiefs, the solar associations of Uplera Mermetma, Uplera Warwarha may be linked to indigenous notions of divinebeauty and ancestral power as displays of 'brilliance', 'radiance' and 'luminosity', rather than to the existence of a solar cult. 
Luang as an ambivalent amalgam of Setan and Tuhan (the 'Devil' and 'God'), and is regarded as the singular incarnation of the different powers associated with each of these beings. ${ }^{13}$ According to the Upa Hrui narrative, the destructive actions of the sailfish caused the mountain to shake so much that the peak fell off, landed in the sea, and became the island of Mnolawna. With its connection to the middle of the island, Mnolawna is also identified as the anchor of Luang, preventing the island from drifting away in the strong southerly currents. The earthly conduit to Upléra Mermetma, Upléra Warwarha is still located on the summit of the mountain, now known as Mnolawna, and is guarded by a being which sometimes presents itself in the shape of a cat $\left(o^{\prime} h a\right)$. Interestingly, while Mnolawna is identified as an island which has a 'history' (BI pulau yang bersejarah), it is not generally regarded as a keramat ('sacred') site.

In his review of marine tenure in the Torres Strait, John Cordell observes that reefs, shoals, rocks and open sea are not only named after events but, when considered in their entirety, constitute a detailed seascape. Cordell (1984:307) defines this seascape as 'a living history with associated myths, stories and legends that provide moral and cultural guidelines. It is the storehouse of social identity for islanders'.

James Weiner (1991:32) succinctly captures this relationship between names, space and social identity when he states that 'a society's place names schematically image a people's intentional transformation of their habitat from a sheer physical terrain into a pattern of historically experienced and constituted space and time'. As Cordell and Weiner suggest, names are not 'inert, lexical labels for places'. Rather, 'place names have their origin in discourse, and it is within discourse [...] that places are named' (J. Weiner 1991:45). In the sea cosmologies of the people from Luang, named places in the coastal zone and the reef environment are also invigorated by the presence of powerful beings.

The beings which are associated with named places are variously described as 'witches' or 'ghosts', 'malevolent figures', 'ancestors', 'chiefs' and 'people' (BI suangi, iblis or setan, moyang, datuk or orang). While these various entities are often granted basic anthropomorphic characteristics, as Valerio Valeri (2000:25) points out in his discussion of 'occult powers' among the Huaulu of Seram, the use of the appellation 'superhuman' to describe these figures is inadequate as it fails to grasp the often 'subhuman' or 'inhuman' features of these beings. Like the occult powers identified by the Huaulu, the beings associated with Luang are 'wild at heart' (Valeri 2000:26), and their mediat-

13 While this reference to Setan ('Devil') and Tuhan ('God') implies some similarity with a Judaeo-Christian moral cosmos, particularly the opposition between good and evil which we find in the latter, there are also considerable differences in the way morality is construed on Luang. Marshall Sahlins (1985:17) provides an example of the way in which indigenous moral universes differ from the Judaeo-Christian one when he observes that, 'many Oceanic societies [...] employ the aesthetic at the boundaries of the moral'. 
ing presence in the reef environment contributes to a dangerously unstable and uncertain landscape. For people on Luang, the presence of these powerful agents also configures a discursive landscape which is redolent with all kinds of sexual tensions and perversions.

These beings are also ascribed a somewhat exuberant sexuality and a range of gendered identities. At times, these identities can appear to be singular in nature, yet at other times can be quite ambivalent or polymorphic. For example, Toronlawna, a submerged reef in the Mettriralma complex, is associated with the presence of an old woman who is likened to 'Satan', and is thus regarded as paling jahat (BI 'very evil'), particularly at the time of a full moon. At this time, the gender neutral suangi figure (BI akin to a 'witch' or a 'sorcerer') at Watlawna, another point in the reef complex of Mettriralma, travels across the lagoon to have bestial sex with the old woman at Toronlawna, mounting each other in the manner of 'dogs'. This is a dangerous time to be anywhere near these two places, as it is possible for the voracious sexual desires of the beings to be turned upon any humans encountered. It is through these acts of excessive, demonic sex that the beings not only reveal their animal-like nature but also highlight the vulnerability of humans to their bestial charms and unprovoked attempts at seduction.

For example, at Mo'ora Tawnu, identified at the 'tip of the [home] reef' (BI ujung karang), an ancestral woman from Luang (from the founding village of Mnyettumjau) is mysteriously impregnated by the semen of a man from Melai Watukali. He places his semen in a bamboo receptacle and sends it to her across the sea. After throwing the bamboo container away several times, she decides to keep it and use it as a pillow. Not long afterwards she has a bastard son. ${ }^{14}$ Soon after the birth of the child, a perahu carrying the man from Melai Watukali arrives at what remains of the island of Luang, the mountain of Wu'urplalahwa ('Long Mountain'), and moors alongside of it. Evocative of sexual union, the perahu and the mountain become fused, and what was once deep water (hleta) becomes land. The perahu is transformed into the mountain Wu'urluli, creating the twin-peaked form of the current island of Luang, and its anchor becomes the large rock known as Watgarniha. In the narrative, the woman from Luang and the man from Melai are also fused together into a single body, one side male, the other half female. Informants referred to this coupling with the Indonesian term for coitus, mereka bersetubuh ('they became one body').

In the same reef complex, at the rocky islet of Kokpinidonni, a woman from Luang repeatedly engages in sex with several men, disregarding the demands of elders to stop. Shamed by her actions, the elders drowned the woman at

14 Debbora Battaglia (1990:40) notes that on Sabarl Island women believed that they could 'somehow become pregnant in the sea'. She suggests that this belief may stem from the image, associated with ambergris, of 'congealed father's blood adrift on the sea headed towards the shores of the living' (Battaglia 1990:223). 


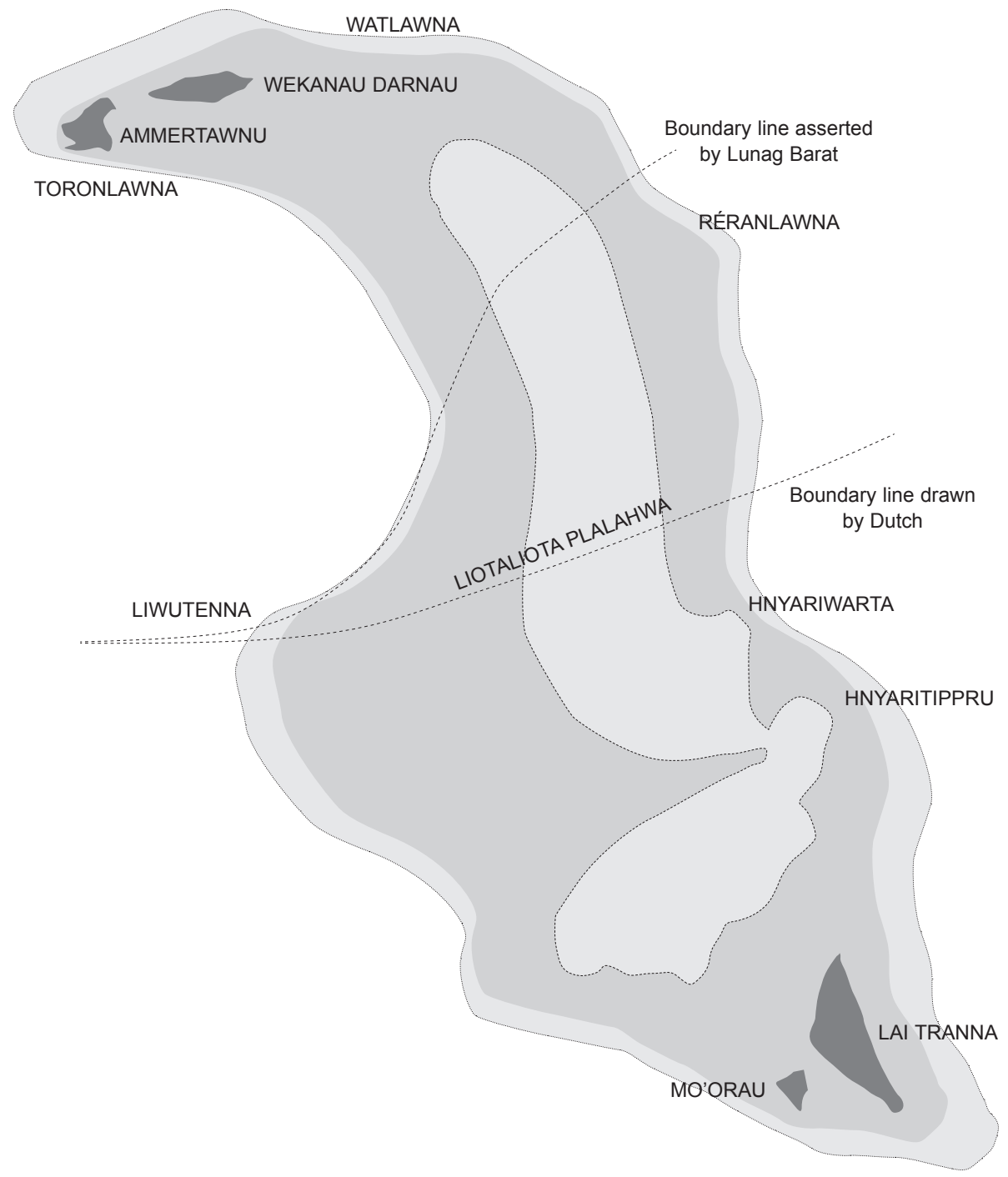

Map 3. The reef complex of Mettriralma 
Kokpinidonni, giving her name to the place where the sexual acts and the drowning occurred. ${ }^{15}$ While I use the past tense here, the woman, like the figures at Toronlawna and Watlawna, is regarded as occupying Kokpinidonni in the present and capable of seducing men who venture into the vicinity. While the men of Luang engage in banter with each other about the keramat site, Kokpinidonni, they also realize that succumbing to these sexual temptations will result in a fatal copulation. One is reminded here of pontianak (BI), promiscuous, supernatural female figures which seduce men with their charms and then castrate them with their claw-like fingernails. ${ }^{16}$ In the pontianak accounts I have recorded in village communities in Maluku, these beings are usually associated with people's experiences of regional centres. The pontianak stories are part of a discourse in which cities like Ambon, Tual and Dili, constitute alienating landscapes, where self-conscious perceptions of social difference and economic disadvantage intersect and are made all too visible. As Roland Barthes observed, the city is the very 'place of our meeting with the other' (quoted in Jacobs 1996:4).

In the seas of Luang, this sense of otherness is primarily articulated in terms of the unregulated and ambivalent sexuality of the occult beings. The animated presence of these beings confronts people with the dangerous ambiguity inherent in the constitution of their own human identity and that of other things. In this sense, the world of humans is constantly haunted by images of similarity and difference, and the possibilities for other kinds of identities. This idea of ambivalent identity is deeply embedded within the shifting seascape of Luang - a valley is a deep-water harbour, a hill is a boat, the summit of a mountain is an island, an island is an anchor, a rock is an ancestor or a boat, and so on. Objects and subjects are never quite what they appear to be in this promiscuous intermingling of identity and order. In this respect, Alain Corbin's depiction (1994:14) of the littoral zone as a 'dangerous area in which the activities of deities, human beings and animals, living in confused, dangerous proximity, threaten to interfere with one another', equally describes the troubled seascape of Luang.

In a discussion of the magical potency of witches to create islands and sea passages, S. Tambiah notes that a common theme in Trobriand narratives is how these beings are eventually stabilized as rocks. In Tambiah's words (1985:303): This stabilisation of the witches, then, allows for their becoming agents for granting (restricted) benefits, and their locations appropriately become shrines for propitiation by kula sailors.

15 Cécile Barraud (1985:122) notes that in Tanebar-Evav society in the Kei Islands couples engaged in incestuous relations were traditionally 'cast into the sea to drown'.

16 In this respect, pontianak are similar to sundel bolong ('prostitute with a hole in her') which Geertz (1960:18) describes as a 'beautiful naked woman' with a hole in her back who seduces men and castrates them. 
The process of physical stabilization that Tambiah refers to not only applies to individual witches but to the cosmological accounts which feature these witches. This is an important consideration, as the representation of these stories in terms of concrete objects points to a social environment in which inter-subjective communication and understanding is construed as part of a phenomenal landscape which is both enduring and changing in its very nature.

Like the Trobriand Islanders, people on Luang also recognize the need to engage with and, if possible, to appease the beings at Toronlawna and Watlawna. These beings and others like them are regarded as both the original owners of the sea and the ones responsible for producing a continuous supply of valuable resources in the marine environment. Similar to the situation Valeri (2000) describes for the Huaulu of central Seram, human ownership of the lands and seas of Luang is thus regarded as derivative. In this situation, there is no sense of total human ownership. To quote Valeri (2000:308), 'one always owns as part owner, as part of a superior [occult] ownership; one is forever an interloper or at best a tenant'. As Valeri points out, this idea of ownership is far removed from the notion of property as a reified and inanimate possession. Like the Huaulu, for people on Luang ownership entails confronting, cajoling and pacifying the non-human beings who live in the sea. One cannot access and use the products of the sea with total freedom and impunity. In this sense, the right to own and use an area or a resource is contingent upon and is mediated by a relationship between the user and a powerful being. Given the fundamental role ascribed to these beings in the reproduction of people's livelihood, it is not so surprising that they are primarily spoken of in terms of the leitmotif of sex. However, the very presence of these beings also highlights the destructive and fatal consequences of uncontrolled reproductivity, expressed in the being's overly exuberant sexuality.

The beings and the places they inhabit are regarded as keramat (BI) and there are a number of taboos associated with them. These beings are identified as possessing 'hot' (BI panas) or 'heavy' (BI berat) names, and the indiscriminate uttering of their names can result in injury or death. As people stated, these beings are capable of 'cutting your throat'. In order to publicly say the names of these beings, and recount the stories associated with them, it is necessary to sumpah sopi (BI) - a ritualized drinking and spilling of palm spirit which entails an avowal of truth. When a person's actions or statements signify a discontinuity with the truth constructed in local discourse, then the vow acts like a curse, and sudden death becomes the fate (BI 'segera jatuh mati'). As Kenneth George (1996:133) observes in his discussion of ritual violence in Sulawesi, oathmaking is not necessarily 'the outcome of powerful emotions, but of powerful obligations made in discourse'.

In order to sail near places regarded as keramat (BI) without encountering immediate misfortune and death, people avoid wearing red clothing and 
maintain a respectful silence. ${ }^{17}$ To emphasize the 'hotness' of keramat sites, a cautionary tale is told about the fate of a fisherman from the island of Leti who, ignorant of the keramat status of Mo'ora Liwutenna, not only wore a red shirt but who also spoke the wrong language in its vicinity. According to local accounts, a large wave suddenly appeared, capsized the boat, and drowned its occupant. ${ }^{18}$

The association of the sea with what appears to be an uncontrolled and dangerous sexuality, epitomized by places like Kokpinidonni, also conjures up related images in the western tradition of mermaids and sirens. In a similar vein to the Greek myth of the singing sea nymphs, places like Kokpinidonni, Toronlawna and Watlawna signpost natural features of the reef system which pose a possible physical hazard to sailors and fishermen. While there is a temptation to posit a functional explanation for this relationship between cosmology and geography, I should point out that the most dangerous features of the reef for shipping, the narrow and shallow passages through the barrier reef, are not associated with either 'libidinous' or 'dangerous' beings.

Places like Kokpinidonni, Toronlawna and Watlawna also represent points in the social landscape where emotions and social values coincide. The sea worm festival in western Sumba represents a similar conjunction of space and sentiment. Janet Hoskins (1983:205) describes how in the waxing light of the moon, the beaches around Kodi in the month of February are awash with the swarming 'sexual dance' of sea worms and humans. While Hoskins invokes a logic of analogy between the fertility of the sea and human sexual license, I would like to go one step further and suggest here that places like Kokpinidonni are focal points in a discourse which produces 'promiscuous geographies of dwelling in place' (Jacobs 1996:5). In speaking of promiscuous geographies, Jane Jacobs (1996:5) has in mind the ever-shifting negotiations of identity and difference which arise from the 'cohabitation of variously empowered people and the meanings they ascribed to localities and places'. As Jacobs (1996:5) points out, in this notion of politically-engaged, impassioned space 'the categories of Self and Other, here and there, past and present, constantly solicit one another'.

For the people of Luang, this particular experience of dwelling in place, epitomized by the solicitous relationship between themselves and powerful beings, is in a continual state of tension. On the one hand, the features and actions of these beings suggest that they share the same values and concerns as humans. Yet, on the other hand, their non-human attributes and often inhuman

17 In many parts of Maluku, particularly in Maluku Tenggara, the wearing of red cloth is associated with warfare, specifically headhunting.

18 The dangerous potential of 'sacred' sites for both locals and outsiders is a belief also found among indigenous people in Australia. For example, Memmott and Trigger (1998:119) report that there are coastal and offshore 'Dreaming' sites that can create heavy rain, strong winds, rough seas and even cyclones if interfered with by outsiders. 
behaviour points to their transcendence of the human order, or perhaps to the extremes possibilities of the human condition. By avoiding or minimizing contact with these beings through the observation of a series of prohibitions and prescriptions, people on Luang attempt to neutralize the moral effects of a perceived continuity between themselves and these non-human entities. As Valeri (2000) points out, taboo in these situations often marks both a relationship of similarity and effects a recognition of difference. In the dangerous waters of Luang, the maintenance of this difference, in the form of the social order and relations of the community, is always a profoundly unstable enterprise.

In this ambivalent experience of dwelling in place, the people of Luang are not alone. They inhabit a landscape which is 'doubly [and even triply] occupied' (Stewart 1997). For in addition to humans, powerful, promiscuous agents such as the suangi figure at Watlawna, the landscape of Luang is also inhabited by the 'undead'. For people in the village of Luang Timur, the island of Wekanau Darnau is identified as the place of the dead. To get to Wekanau Darnau, the dead travel along a specific path or straat, as one informant called it. From Luang they travel to Hu'ulagain, another keramat site associated with a powerful being, from there they cross the deep waters between Luang and Mettriralma, to Réranlawna ('large forehead'), another keramat site, and then onto the island of Wekanau Darnau. The place of the dead is described in somewhat heavenly terms; the houses are larger, there is an abundance of food and, importantly, palm spirit; no one works, and the women are beautiful. People who suddenly become sick and die soon are said to have dreamed of Wekanau Darnau and been seduced by its very earthly attractions.

The island closest to Wekanau Darnau, Ammwertawnu is identified as the place of the dead for people from Lakor, while the dead from Luang Barat travel to the islet of Mo'or au ('reef where trees grow'), again in the Mettriralma reef complex. Upon reaching Mo'orau, Wekanau Darnau or Ammwertawnu, the dead are revivified and, in the words of my informants, become 'human again' (BI menjadi manusia lagi), in the process, achieving a state of very un-humanlike immortality. Thus, it is possible, and not uncommon according to local accounts, to encounter the dead as they travel across the seas towards the keramat sites of Wekanau Darnau, Ammwertawnu or Mo'orau or to encounter them at these islands. As this suggests, the undead do not relinquish their bodily existence at death, and it is this inability to distinguish the undead and other beings from ordinary humans and animals which 'makes them dangerous' (Valeri 2000:24). While not regarded as dangerous as the beings at Toronlawna and Watlawna, the undead are capable of distracting people as they sail through the physically challenging reef environment or of interfering with their fishing activities, cutting fishing lines and anchor ropes, for example.

For people on Luang, this landscape of named places and powerful beings is not simply an elaborate sign system for mythological events (see Morphy 
1995:186). Nor is the landscape just a mnemonic or metaphor for processes that are really going on at some other level (see Layton 1995:229). As Morphy and Layton both argue in their respective discussions of Yolngu and Pitjantjatjarra landscapes in north and central Australia, 'landscape is conceived within a cultural tradition' so that 'the land itself as socially constituted plays a fundamental role in the ordering of cultural relations' (Layton 1995:229). As this last comment suggests, for Aboriginal people landscape is not so much a text to be read but the discursive ground for the consummation of ancestral actions and human experiences. Michael Taussig's explanation (1980:15) in 'The devil and commodity fetishism' for the revelatory power of magical beliefs equally applies to landscape - both resonate with the 'poetic echoes of the cadences that guide the innermost course of the world'. In the context of Luang, the cosmological landscape resonates with the social passions and power struggles of 'ordinary, everyday life' (Geertz 1973:443). In this sense, cosmologies can be viewed, to paraphrase Clifford Geertz (1973:448), as the 'stor[ies] people tell themselves about themselves'. However, they are more than just 'meta-social commentaries' on ordinary, everyday experience.

As I argue in the following sections, cosmological narratives create, articulate and, at times, manipulate what E.V. Daniel (1990:27) identifies as 'epistemic and ontic realities'. That is, they provide people with a way of 'seeing and being' in the world. Considered as 'vital form[s] of social action' (Malkki 1995:105), these discourses have both reflexive and very real consequences, linked as they are to ideas about sacrality and local assertions of sovereignty.

\section{Cosmology, sovereignty and the sacred}

Echols and Shadily (1978:182) gloss the Arabic-derived term keramat as 'sacred', 'holy' or as 'having supernatural qualities'. In the anthropological literature, the term is often applied to rituals, objects or sites associated with founding or ancestral figures, linking the potency of an action, a thing or a place to divine or supernatural power, grace or energy (see Bowen 1993:197; Geertz 1980:106). This connection between place, ancestors and sacrality is also evident in the literature from Aboriginal Australia and the Pacific. For example, in Australia 'sacred sites' are described as places associated with the travels of ancestral beings and the transformation of these beings into named places (see Morphy 1995). In the Pacific, Edward Hviding (1995:250) discusses 'sacred sites' in the barrier reef areas of Marovo Lagoon which are 'connected with genealogically placed ancestors' and linked to certain taboos. While in eastern Indonesia, Andrew McWilliam (1996:154) describes how the concept of $l e^{\prime} u$, which carries the 'sense of sacred or taboo', is 'intimately connected to the hidden world of ancestors, spirits and the supreme being ' and, at the time of headhunting raids, was focused upon the site of the 'hostility' cult house. 
In the landscape which emerges in the cosmological accounts from Luang, the concept of keramat is not just linked to named places and powerful 'supernatural' beings, but it is also positioned at the centre of a discourse on morality, sexuality and ultimately the nature of sociality. Implicated in this discursive topography of promiscuity, violence, danger, and power, keramat in this context represents a peculiar or 'uncanny' (Gelder and Jacobs 1998) form of the sacred. A kind of 'impure sacred', to borrow Durkheim's expression for the idea that not only 'God but evil is part of the notion of sacredness' (Taussig 1992:114). As Michael Taussig (1992:111-4) points out, both fear and reverence, respect and horror are intertwined in this double helix of the sacred. Going well beyond Durkheim, and the posturing of the sacred in terms of the double act of good and evil, he links the ambivalent quality of the sacred not just to society, but to the 'cultural practice of Statecraft' (Taussig 1992:115). For Taussig (1992:116), it is the inter-penetration of the sacred with the impure and the erotic, and its link to the 'trafficking' between rationality and violence, which contributes to the attraction and repulsion of the state.

Like Taussig, Phillip Winn (2003) draws our attention to 'the involvement of the sacred in local questions of power, autonomy and sovereignty' in some of the writings on headhunting in Indonesia. For instance, in his account of 'history, politics and headhunting in southwest Timor', McWilliam (1996:146) discusses how the:

Development of the political domain under Nabuasa leadership was constituted as both a political and a religious system. The continuing prosperity of the wider political community was underpinned by an ongoing communication with the hidden world of ancestors and spirits.

Picking up on this relationship between politics and cosmology, Kenneth George (1996:69), in his discussion of the cultural politics of headhunting, argues that 'cosmographic ideas can shape and take shape from a lived-in ethnic and political terrain'. Crucial to George's analysis is the role played by the 'grotesque' in the political economy of ritual headhunting. By 'grotesque', George (1996:92) has in mind: The kind of imagery and discourse that foreground the monstrous, the fantastic and bizarre, the exaggerated, the incongruous, and the terrifying or awe-provoking.

As George (1996:96) remarks, the grotesque imagery of headhunting 'lies at the heart of traditional upland 'official' discourse and power'. In his work, the grotesque is foremost a 'mode of political discourse' (George 1996:100), akin in many ways to Taussig's discussion of the insinuation of the impure sacred in the cultural practices of the state.

In the final sections of this article, I briefly explore this relationship between the 'grotesque'/ 'impure sacred', cosmology, and sovereignty within the context of boundary and marine resource disputes in Luang. 
Domains of difference, polities of power

All of the named places and beings mentioned so far are associated with one of the eleven polities which originally occupied the summits of the eleven hills on Luang. In the middle or 'navel' of the island (nohophoraraiapnu) was located Uhutéla'a, Mnyettumjau, Watihli Wattriha (also known as Lettra Wo'ora) and Lakkamno'a. In the front or 'face' of the island (nohulugairierna) was Wettagai Lettra, while at the back or 'tail' of the island (nohuputnaraitiawnu) was Watulu Harulu, Mnowaru, Wo'ormaha, Ihlura Watunhora, Melai Watukali and Noknokamaupéhi.

Often described as kampung lama (BI) or leta tgakmu ('old village'), the physical remains of these eleven polities are evident as a series of multi-terraced, stone-walled compounds. According to local narratives, the present-day indigenous residents of Luang (known as ornoha or orleta, 'people of the island' or 'people of the village') are the descendants of the original occupiers of the five polities which remained on Luang after a period of prolonged warfare involving all eleven hill-top states. As previously mentioned, people from six of these leta were forced to flee the island due to local hostilities, and the descendants of these original occupiers can be found throughout the province of Maluku.

People on Luang trace the origins of the leta rahuna (BI soa) $)^{19}$ on Luang, and their constituent rahuna $a^{\prime} n a$ (BI marga) or 'house' groups, to the ancestral figures associated with the remaining five original states. According to local narratives, the occupiers of the remaining five village-states descended from the original leta sites and settled together on either the east or west coast of Luang, forming the physical and social foundations for the present village communities of Luang Timur and Luang Barat. Upon leaving the original hilltop leta sites, the original occupiers acquired new names which reflect the circumstances of their descent and settlement. Today, these names are identified as referring to marga (BI) or 'house' groups (for example Romailioha, Romhadi, Romlawna).

Depicted in narratives as autonomous sovereign entities, each of the eleven polities asserted authority over specific areas of land ( $r a$ ) and sea (lora), the geographic extent of which was cosmologically decreed. The extent of these domains is marked by named places, and the topographic features, powerful beings and human-made signs associated with them. As one informant observed, speaking of the history of the western-most point in the home reef known as Mo'ora Tawnu, the original polities placed ancestral or other figures in the landscape to establish the name of a place and to give a physical presence to their assertion of territorial authority. ${ }^{20}$ These site-specific beings are

19 In the village of Luang Timur, there are four soa; Tuprulu Gérlorna, Pupugéni, Hinléli and Pépupun Tra'upun, while in Luang Barat there are three: Horupun, Tiataupun and Lewnupun.

20 Dulu Melai Watukali kas turun orang di Mo'ora Tawnu, kasih tanda sebagai hak. 
referred to in the local language as marna watu onni, 21 'the ones who guard the stone', a reference to the stone shrines (nattra) which form the focus of each of the eleven original polities and those sites identified as keramat. The 'stones' and other markers used to indicate the extent of the interests of each of the different polities are known as ghéra li'ai, a term which is glossed in Indonesian as sasi (see Pannell 1997b). A local narrative describes the origins of the different signs used to mark territorial interests, ascribing different signs or markers to each of the original polities which remained on the island after the period of the great wars. The name of one of these polities, Ihlura Watunhora, actually refers to the particular mark used by it to indicate its sovereign interests. The name of this polity can be glossed as 'the ones who lived on top of a high mountain and who placed a stone in the ground'. While stones, lontar leaf containers, and a hole created by an ancestral spear mark the interests of the different polities on land, in the sea, named places in the reef complex, which are also associated with various beings, perform this role. It is important to realize here that as markers of sovereign interests, ghéra li'ai do not constitute linear alignments of physical objects in space, in the manner of a wooden fence or a stone wall. Rather, ghéra li'ai are named places in the landscape which are not only identifiable physical entities but also the products of discourse. In this sense, ghéra li'ai focus local statements about sovereignty, identity and history. 22

\section{A line in the water: gods and monsters II}

The relationship between cosmology, geography and sovereignty has been the subject of on-going disputes and open hostilities between people from Luang Timur and Luang Barat for at least the past hundred years or so, perhaps even longer. One of these disputes pivots around the identity of the ancestral being occupying the northern islands of Wekanau Darnau and Ammwertawnu, and the geographic extent of the territorial interests and resource rights of both villages in the reef complex of Mettriralma. A number of people link the genesis of this particular dispute to increased demands for marine resources, such as trepang and trochus shell, and identify the intervention of agents of the Netherlands Indies colonial state in the late 1800s as exacerbating the situation. As one senior informant stated, before the intervention of the Dutch, there were no boundaries or lines which bisected the reef complex of Mettriralma into exclusive regions. While there may not have been a boundary per

21 Informants glossed this indigenous expression in Bahasa Indonesia as penjaga sasi.

22 Interestingly, when translating statements about the sovereign interests of the various founding villages, informants also used the Indonesian term sifat, rather than batas, to describe these named points in the landscape. In the Echols and Shadily Indonesian-English dictionary (1985), sifat is glossed as 'quality', 'characteristic' or 'prospect', while the meaning of batas is given as 'limit', 'border' or 'boundary'. 
se, areas of Mettriralma are historically linked to different founding polities and a number of ancestral beings.

According to some accounts, Wo'orau, an ancestral figure from the village of Watulu Harulu, is identified as the first being to die and travel to and inhabit the northern islands of Wekanau Darnau (also known as Lai Riar'i) and Ammwertawnu. In doing so, Wo'orau established the identity of these islands as the 'place of the dead'.

According to another account, however, the islands of Wekanau Darnau and Ammwertawnu are controlled by a dangerous old woman known as Rarweru Rarwatu from Watulu Harulu, the same ancestral village as that of Wo'orau. According to this account, an ancestor from the village of Wo'ormaha caught the old woman stealing his palm wine. To punish her, the ancestor from Wo'ormaha decreed that she could only eat from the islands of Wekanau Darnau and Ammwertawnu, which the village of Wo'ormaha claimed authority over. In this account, the ancestral occupiers of Wo'ormaha assert a sovereign right over the entire Mettriralma complex, including Meti Miarang (also known as Lai Tranna), the sand island in the southern part of the reef complex.

While the two ancestral figures associated with the islands of Wekanau Darnau and Ammwertawnu are from the same leta, the fundamental difference between these accounts, a difference which lies at the heart of the disputes, is the issue of precedence and agency. In the first account, Wo'orau precedes all others and independently establishes an authoritative and lasting presence on the island, while in the second account, the connection of Watulu Harulu to the island is predicated upon the actions of an ancestral figure from a more powerful polity with prior interests in the island. In both accounts, however, the territorial interests of Watulu Harulu appear to be confined to the islands of Wekanau Darnau and Ammwertawnu, and perhaps the immediate vicinity.

People who claim descent from the ancestors of Watulu Harulu live in Luang Timur, while the descendants of the ancestral occupiers of the village state of Wo'ormaha reside in the village of Luang Barat. These descendants have inter-married with members from other 'house' groups in the two villages, contributing to a situation where proprietary claims to Mettriralma are primarily expressed in terms of contemporary village identities (as in, Luang Timur and Luang Barat) and not individual 'house' or even 'family' identities, as some people argue should be the case. As previously indicated, the physical extent of the interests of the two villages in Mettriralma has been the source of considerable contention between the two communities.

In all local accounts regarding the sovereign identifications of Mettriralma, the keramat site of Liwutenna is identified as the 'feature' (BI sifat) which marks the divergence of interests of the two villages. Situated at the most westerly point in the reef complex, Liwutenna is described as a 'very hot' place, associa- 
ted with an extremely dangerous being. People from both Luang Barat and Luang Timur acknowledge the potency of Liwutenna and are aware of the unfortunate fate which awaits those who transgress past this point. Traditionally, Liwutenna constituted the only ghéra li'ai in the Metrriralma complex which exerted a powerful, and limiting influence upon the movements and activities of villagers from both communities.

At some point in the late 1800s or early 1900s, the issue of the delineation of sovereign interests in Mettriralma came to a violent head and the Dutch 'district officer' (controleur) for the area intervened. There is some suggestion that the fighting was triggered by accusations that people from each community were poaching marine resources, particularly trepang, from the other's area. The event which marked the supposed resolution of the dispute consisted of an interesting amalgamation of state and local 'native political rituals' (Sahlins 1981). In true colonial fashion, the Dutch formalized the divergence of interests of the two communities by introducing a boundary and erecting stone cairns to mark the western and eastern points of this line in the water. ${ }^{23}$ In doing so, it could be said that the Dutch attempted to place their own gods and monsters in the politically-charged, cosmological landscape of Luang.

In selecting an easily identifiable physiographic feature, known locally as Liotaliota Plalahwa, a large area of 'deep water', as signalling the eastern point of this border of difference, the Dutch effectively cut the reef system of Mettriralma into two. Luang Timur would control the northern half, while Luang Barat exploited the southern section of the reef system. Unbeknown to the Dutch officials, their own cultural practices of statecraft nicely dovetailed with local political rituals concerning the assertion of sovereign right. The western point chosen by the Dutch to mark the boundary was the physically obvious western tip of the reef complex. As previously mentioned, this point is known locally as Liwutenna, a keramat site implicated in the local landscape of sovereign power. For people on Luang, the presence of the powerful being at Liwutenna constituted a far more effective influence on people's movements than any stone cairn erected by the colonial state. Interestingly, the stone cairn that was erected at this point was not seen as desecration of this site. On the contrary. The stone marker erected by the Dutch at Liwutenna was regarded as recognition of the keramat status of the site, with the cairn likened to a traditional ancestral shrine (nattra).

To mark the event, the local government heads (BI orang kaya) from Luang Timur and Luang Barat, journeyed to Liwutenna and at low tide, spread a locally 'woven cloth' (BI kain tenun) on top of the exposed reef and together

23 As Moore (1996:135) points out in his discussion of environmental struggles in Zimbabwe, 'the separation of cordoned spaces sanctioned by property deeds' is a characteristically colonial practice 'critical to state control of subject populations'. This practice, as Osseweijer et al. (2003) observe, is not confined to a colonial past but is readily invoked by contemporary governments and non-government organizations. 
they sumpah sopi (BI). While the Dutch officials may have viewed the ritual drinking of palm spirit at Liwutenna as a quaint, local conclusion to the cairnerecting ceremony, for people from Luang the drinking and spilling of sopi did not mark the end of the dispute. Nor did it signal or celebrate local recognition of the sovereign power of the Netherlands Indies State. Rather, this political ritual was aimed at establishing whose claim to sovereign authority was cosmologically authenticated by ancestral potency (compare A. Weiner 1992). In this search for truth, so one account goes, the orang kaya of Luang Timur died soon after the sopi ceremony, losing his tongue as a result of a mysterious cut to it. For people in Luang Barat, the alleged death of the orang kaya from Luang Timur is interpreted as evidence of the cosmological righteousness of their claims to the reef system.

The establishment of a state-sanctioned boundary at Mettriralma did not herald the cessation of hostilities between the two village communities. Rather, the colonial introduction of a line in the water triggered off new arguments about the location of this bureaucratic border and the gods and monsters associated with it. The disputes revolve around the site which marks the extent of the interests of the two villages on the eastern side of the reef. The marine feature selected by the Dutch, Liotaliota Plalahwa, as signalling the approximate location of the eastern point in the boundary, is a cosmologically neutral and ancestrally devoid area of water in the reef system. While all parties acknowledge the 'occult' significance and power of Liwutenna in the west, and there is no suggestion of abandoning this site as a boundary marker, in the east there are attempts to re-anchor the border to a site which is cosmologically empowered in local discourse. Thus, people from Luang Barat argue that the ancestral interests of people from Luang Timur are confined to the region of Wekanua Darnau. Accordingly, they stipulate that their interests do not extend beyond Réranlawna, a dangerous, ancestor-inhabited keramat site in the northern section of the reef complex. Drawing upon the cultural logic of previous state territorial practices, as further evidence for this assertion they point to the existence of a 'straat' between Réranlawna and Liwutenna which is said to be free of rocks and is likened to a 'main road' (BI jalan raya), linking the two named markers. Indirectly acknowledging the authoritative limits of their ancestral claim to Mettriralma, people from Luang Timur insist that Liotaliota Plalahwa marks the boundary in the east. In doing so, they harness their claims to the cosmological authenticity of another divine power - the state. Indeed, it is apparent that in the guise of desa (BI) or 'village governments', both communities draw upon the 'mythic power' (Taussig 1992:122) or totemic energy of the Indonesian state to further authenticate their assertions and actions. In recent years, both desa have been busy erecting and reerecting stone cairns at Mettriralma in the name of this organ of supreme potency. 


\section{Conclusion}

The sacred and sovereign power enshrined in stone erections (also in stone objects and monoliths) has long been recognized in Australian Aboriginal anthropology. ${ }^{24}$ Writing of oval or oblong-shaped stone objects called 'Churinga' by Aranda people, Durkheim (1965:141) observed that these objects are not only 'eminently sacred things' but their potency is also intrinsically linked to the patriarchy exercised by initiated men. The power of these objects is sensually communicated to the men by rubbing the greased boards and stones across the lower parts of their bodies. As Durkheim (1965:143) points out, these objects are both desired and adored, and their loss is the 'greatest misfortune which can happen to the group'. While Durkheim viewed Aboriginal religious adoration of 'Churinga' as ultimately the fetishization of society, the sentiments associated with these objects also attach to the ancestral environment which the objects are regarded as manifestations of. While this latter point is much overlooked in Durkheim's treatment of Aboriginal totemism, it occupies a central place in Géza Rohéim's analysis (1945) of Aboriginal myths from Central Australia.

Rohéim observes that these myths are 'full of phallic heroes, who march gloriously and triumphantly across the landscape performing rituals as they go, rituals whose libidinal origins are evidence by forms of symbolic sexuality' ${ }^{25} \mathrm{He}$ argues that through ceremonial participation, Aboriginal people's relationship to the environment has been thoroughly 'libidinized' (Rohéim 1945:9). According to Rohéim, the libidinization of the landscape functions to make a virtue out of the necessity of a nomadic way of life in a 'harsh' desert region. While mindful of the limitations of his psychoanalytical approach, and T. Strehlow's criticism (1971:xlii) that Rohéim was duped by his informants who 'liberally' supplied him with 'odd' or 'unusual sexual information', Rohéim's work does, however, alert us to the explicit sensual and sexual nature of indigenous (and non-indigenous) cosmologies. ${ }^{26}$

One is reminded here of Sahlin's description of the Hawaiian cultural order as 'a political economy of love' (Sahlin 1985:19), where sex is both everywhere

24 For example, in their book, Uncanny Australia, Gelder and Jacobs (1998) discuss how Uluru ('Ayers Rock') is a 'meta-sacred site' which stands at the centre of a discourse on nationalism and Aboriginal land rights.

25 Morton 1988:xx. In another analysis of myths from Central Australia, Isobel White (1975) discusses the violent nature of sexual relations depicted in these accounts. Arguing that myths generally can be seen as a 'charter for the values of society, as represented in desires and fears', White (1975:138) concludes that the 'violence of sexual relations in Central Australian myths [is] a reflection of the sexual values of a male-dominated society'.

26 One is reminded here of Simon Schama's discussion (1995) of the 'primitive' Arcadian landscape depicted in Greek myth. Contrary to later depictions, the original myth constructed Arcadia as 'the playground of the unchained senses' (Schama 1995:530), marked by the interplay of 'bestiality', 'brutishness', 'wildness' and 'fecundity'. 
and 'everything: rank, power, wealth, [and] land' (Sahlin 1985:26). Both Rohéim's notion of a landscape invigorated by a 'promiscuous sacredness' (Gelder and Jacobs 1998:117) and Sahlins' idea of a kingdom structured by beauty and sexual attraction takes us beyond the usual male-female symbolism reported for indigenous cosmologies and, for that matter, beyond the anthropological tradition of narrowly understood political systems.

References to the sensual, political, erotic, and aesthetic scenery of sociocosmological landscapes, which we see so compellingly explored in the work of Rohéim, Sahlins, and others like Simon Schama (1995), are largely muted in, if not absent from, discussions of indigenous cosmologies from Indonesia and Australia. Indeed, as Franca Tamisari points out with respect to writings on Aboriginal cosmologies and epistemologies, it is only relatively recently that the 'poetic', 'affective' and 'experiential' aspects of the relationship between Aboriginal people and country (both sea and land) has been considered (Tamisari 1998:249). She suggests that an anthropological preoccupation with social organization, together with an approach to 'land as space rather than a series of experienced places' (Tamisari 1998:250), are underlying reasons for the 'static portrayal' of indigenous cosmological landscapes. Tamisari's comments equally apply to the ethnographic situation in eastern Indonesia, where the study of the 'poetics of place' is in 'early efflorescence' (Fox 1997:3), while the discussion of indigenous sea cosmologies is, for all intents and purposes, still in the bud.

Examination of the anthropological literature on eastern Indonesia reveals that people's relationship to the sea is either spoken of as; a physical 'setting', part of a system of folk orientation based upon a land-sea opposition, a range of economic activities, or discussed in terms of the cultural symbolism of the boat. While there are a considerable number of ethnographic references to the meaning of boats and the widespread association of boats with some form of social organization, by and large, anthropologists have chosen to pass over the significance of the 'boat' in favour of detailed discussion and analysis of the 'house'. As I conclude in a recent article, the anthropological record points to a very 'unromantic' view of indigenous people's relationship to the sea. ${ }^{27}$ If this is the case, then perhaps the 'ethnographic blindspot' I referred to at the beginning of this article should be extended to include the study of indigenous sea cosmologies as poetic topographies of the diverse and sometimes subversive experiences of human life. ${ }^{28}$

27 Pannell 1994. I use the term 'romantic' here to try and capture the kind of sentiments Stephen Greenblatt (1990) speaks of when using the concepts of 'resonance' and 'wonder' to characterize what he calls 'new historicism'. 'Romancing the sea', as an exercise in writing, thus involves capturing the mysterious, the sensual, the dangerous, the erotic and nostalgic qualities ascribed to particular places or spaces.

28 The reference to 'poetic' here draws upon the Greek root of this term, 'poiein', 'to make'. 


\section{Acknowledgements}

This article is based upon approximately four months anthropological research on the island of Luang. This study was supported by an Australian Research Council Large Grant and the award of a Research Fellowship at the Centre for Resource and Environmental Studies at The Australian National University, Canberra. In Indonesia, research was conducted under the auspices of Lembaga Ilmu Pengetahuan Indonesia (LIPI) in Jakarta, and Universitas Pattimura, Ambon. I would like to extend my general thanks and appreciation to the individuals in these institutions who assisted me in the course of this research. I would also like to acknowledge that without the support of the people on Luang this research would not be possible. I am also indebted to Nus Surlia for his work as a research assistant on the project.

\section{Bibliography}

Barraud, Cécile

1985

'The sailing-boat; Circulation and values in the Kei Islands, Indonesia', in: R.H. Barnes, Daniel de Coppet and R.J. Parkin (eds), Contexts and levels; Anthropological essays on hierarchy, pp. 117-30. Oxford: JASO. [Occasional Papers 4.]

1990

'A turtle turned on the sand in the Kei Islands', Bijdragen tot de Taal-, Land-en Volkenkunde 146:35-55.

Battaglia, Debbora

1990 On the bones of the serpent; Person, memory, and mortality in Sabarl Island society. Chicago/London: University of Chicago Press.

Bender, Barbara

1993

'Introduction; Landscape: Meaning and action', in: Barbara Bender (ed.), Landscape; Politics and perspectives, pp. 1-19. Providence/Oxford: Berg.

Bowen, John R.

1993 Muslims through discourse. Princeton, NJ: Princeton University Press.

Carter, Paul

1987

The road to Botany Bay; An essay in spatial history. London: Faber and Faber.

Certeau, Michel de

1984 The practice of everyday life. Berkeley, CA/London: University of California Press.

Corbin, Alain

$1994 \quad$ The lure of the sea; The discovery of the seaside in the Western world, 17501840. London: Polity Press.

Cordell, John

1984

'Defending customary inshore sea rights', in: Kenneth Ruddle and Tomoya Akimichi (eds), Maritime institutions in the Western Pacific, pp. 301-26. Osaka: National Museum of Ethnology. [Senri Ethnological Studies 17.] 
Daniel, E.V.

1990

'Afterword; Sacred places, violent spaces', in: Jonathan Spencer (ed.), Sri

Durkheim, Émile

Lanka; History and the roots of conflict, pp. 227-46. London: Routledge.

1965

The elementary forms of the religious life. New York: Free Press. [First edition 1915.]

Echols, John M. and Hassan Shadily

1985 An Indonesian-English dictionary. Ithaca, NY: Cornell University Press.

Fox, James J.

1997

'Place and landscape in comparative Austronesian perspective', in: James J. Fox (ed.), The poetic power of place; Comparative perspectives in Austronesian ideas of locality, pp. 1-22. Canberra: Research School of Pacific and Asian Studies, Australian National University.

Geertz, Clifford

1960 The religion of Java. Chicago: Chicago University Press.

1973 'Deep play; Notes on the Balinese cockfight', in: Clifford Geertz, The interpretation of cultures; Selected essays, pp. 412-55. New York: Basic Books.

1980 Negara; The theatre state in nineteenth-century Bali. Princeton, NJ: Princeton University Press.

Gelder, Ken and Jane M. Jacobs

1998 Uncanny Australia; Sacredness and identity in a postcolonial nation. Melbourne: Melbourne University Press.

George, Kenneth M.

1996 Showing signs of violence; The cultural politics of a twentieth-century headhunting ritual. Berkeley, CA/London: University of California Press.

Greenblatt, Stephen. J.

1990 Learning to curse; Essays in early modern culture. New York/London: Routledge.

Grimes, Barbara F. (ed.)

1996 Ethnologue; Languages of the world. Thirteenth edition. Dallas, Texas:

Summer Institute of Linguistics. [First edition 1951.]

Herzfeld, Michael

1987 Anthropology through the looking-glass; Critical ethnography in the margins of Europe. Cambridge: Cambridge University Press.

Hirsch, Eric and Michael O'Hanlon (eds)

1995

The anthropology of landscape; Perspectives on place and space. Oxford:

Clarendon Press.

Hoskins, Janet

1983 Spirit worship and feasting in Kodi, West Sumba; Paths to riches and renown. $\mathrm{PhD}$ thesis, Harvard University, Cambridge, Mass.

Hviding, Edvard

1996 Guardians of Marovo Lagoon; Practice, place, and politics in maritime Melanesia. Honolulu: University of Hawai'i Press.

Inglis, F.

1977

'Nation and community; A landscape and its morality', Sociological

Review 25:489-513. 
Jacobs, Jane

1996

Edge of empire; Postcolonialism and the city. London/New York: Routledge.

Jonge, Nico de and Toos van Dijk

$1995 \quad$ Forgotten islands of Indonesia; The art and culture of the Southeast Moluccas.

Hongkong: Periplus.

Kuchler, Susanne

1995 'Landscape as memory; The mapping of process and its representation in a Melanesian society', in: Barbara Bender (ed.), Landscape; Politics and Layton, Robert

perspectives, pp. 85-107. Providence/Oxford: Berg.

1995 'Relating to the country in the Western Desert', in: Eric Hirsch and Michael O'Hanlon (eds), The anthropology of landscape; Perspectives on

Lévi-Strauss, Claude place and space, pp. 210-32. Oxford: Clarendon Press.

1966

The savage mind. Chicago: University of Chicago Press.

McKinnon, Susan

$1991 \quad$ From a shattered sun; Hierarchy, gender and alliance in the Tanimbar Islands. Madison: University of Wisconsin Press.

McWilliam, Andrew

1996 'Severed heads that germinate the state; History, politics and headhunting in Southwest Timor', in: Janet Hoskins (ed.), Headhunting and the social imagination in Southeast Asia, pp. 126-67. Stanford: Stanford University Press.

1997

'Mapping with metaphor; Cultural topographies in West Timor', in: James J. Fox (ed.), The poetic power of place; Comparative perspectives in Austronesian ideas of locality, pp. 103-16. Canberra: Research School of Pacific and Asian Studies, Australian National University.

Maddock, Kenneth and Ira Buchler

1978

The rainbow serpent; A chromatic piece. The Hague/Paris: Mouton.

Malkki, Liisa

1995

Purity and exile; Violence, memory and national cosmology among Hutu refugees in Tanzania. Chicago/London: University of Chicago Press.

Massey, D.

$1994 \quad$ Space, place and gender. Cambridge: Polity.

Memmott, Paul and David Trigger

1998 'Marine tenure in the Wellesley Islands region, Gulf of Carpentaria', in: Nicolas Peterson and Bruce Rigsby (eds), Customary marine tenure in Australia, pp. 109-25. Sydney: University of Sydney. [Oceania Monograph 48.]

Moore, Donald S.

1996 'Marxism, culture, and political ecology', in: Richard Peet and Michael Watts (eds), Liberation ecologies; Environment, development, social movements, pp. 125-48. London/New York: Routledge. 
Morphy, Howard

1995 'Landscape and the reproduction of the ancestral past', in: Eric Hirsch and Michael O'Hanlon (eds), The anthropology of landscape; Perspectives on place and space, pp. 184-210. Oxford: Clarendon Press.

Morton, John

1988

'Introduction; Géza Rohéim's contribution to Australian ethnography', in: John Morton and Werner Muensterberger (eds), Children of the desert; II, Myths and dreams of the aborigines of Central Australia, pp. vii-3. Sydney: Oceania Publications. [Oceania Ethnographies 2.]

Osseweijer, Manon, Gerard A. Persoon, Diny M.E. van Est and Percy E. Sajise 2003

'Conflicting boundaries; The role of mapping in the co-management discourse', in: Gerard A. Persoon, Percy E. Sajise and Diny M.E. van Est (eds), Co-management of natural resources in Asia; A comparative perspective, pp. 173-97. Copenhagen: NIAS.

Pannell, Sandra

1994 'Romancing the sea; An unromantic view from anthropology.' Paper, Third International Conference on Maluku Research, Universitas Pattimura, Ambon, Indonesia, 27 June-1 July.

$1997 \mathrm{a}$

'From the poetics of place to the politics of space; Redefining cultural landscapes on Damer, Maluku Tenggara', in: James J. Fox (ed.), The poetic power of place; Comparative perspectives in Austronesian ideas of locality, pp. 163-74. Canberra: Research School of Pacific and Asian Studies, Australian National University.

1997b 'Managing the discourse of resource management; The case of sasi from "Southeast" Maluku, Indonesia', Oceania 67-4:289-308.

Peterson, Nicolas and Bruce Rigsby

1998 'Introduction', in: Nicholas Peterson and Bruce Rigsby (eds), Customary marine tenure in Australia, pp. 1-22. Sydney: University of Sydney. [Oceania Monograph 48.]

Polunin, N.

1984 'Do traditional marine "reserves" conserve?; A view of Indonesian and

New Guinean evidence', in: Kenneth Ruddle and Tomoya Akimichi (eds), Maritime institutions in the Western Pacific, pp. 267-83. Osaka:

National Museum of Ethnology. [Senri Ethnological Studies 17.]

Radcliffe-Brown, A.R

1926 'The rainbow serpent myth of Australia', Journal of the Anthropological Institute of Great Britain and Ireland 56-24:19-25.

Rohéim, Géza

1945 The eternal ones of the dream; A psychoanalytic interpretation of Australian myth and ritual. New York: International Universities Press.

Sahlins, Marshall

1981

Historical metaphors and mythical realities; Structure in the early history of the Sandwich Islands kingdom. Ann Arbor: University of Michigan Press.

1985 Islands of history. London/New York: Tavistock.

Said, Edward

1993 Culture and imperialism. London: Chatto and Windus. 
Schama, Simon

1995 Landscape and memory. London: Harper Collins.

Stacey, Natasha

1999 Boats to burn; Bajo fishing activity in the Australian fishing zone. PhD thesis, Northern Territory University, Darwin.

Stanner, W.E.H.

1989 On aboriginal religion. Sydney: University of Sydney.

Stewart, Kathleen

1997 'An occupied place', in: Steven Feld and Keith H. Basso (eds), Senses of place, pp. 137-66. New Mexico: School of American Research Press.

Strehlow, T.G.H.

1971 Songs of Central Australia. Sydney: Angus and Robertson.

Taber, Mark (ed.)

1996 Atlas bahasa Tanah Maluku. Ambon: Summer Institute of Linguistics.

Tambiah, S.J.

1985 Culture, thought, and social action; An anthropological perspective. Cambridge, Mass.: Harvard University Press.

Tamisari, F.

1998

'Body, vision and movement; In the footprints of the ancestors', Oceania 68-4:249-71.

Taussig, Michael

1980 The devil and commodity fetishism in South America. Chapel Hill: University of North Carolina Press.

1992 The nervous system. New York/London: Routledge.

Valerio, Valeri

2000 The forest of taboos; Morality, hunting, and identity among the Huaulu of the Moluccas. Madison: University of Wisconsin Press.

Weiner, Annette

1992

Inalienable possessions; The paradox of keeping-while-giving. Berkeley, CA:

University of California Press.

Weiner, James

1991 The empty place; Poetry, space, and being among the Foi of Papua New Guinea. Bloomington/Indianapolis: Indiana University Press.

White, Isobel

'Sexual conquest and submission in the myths of Central Australia', in: L.R. Hiatt (ed.), Australian aboriginal mythology; Essays in honour of W.E.H. Stanner, pp. 123-43. Canberra: Australian Institute of Aboriginal Studies.

Winn, Phillip 2003

'Sovereign violence, moral authority and the Maluku Cakalele', in: Sandra Pannell (ed.), A state of emergency; Violence, society and the state in eastern Indonesia, pp. 49-76. Darwin: Northern Territory University Press. 